\title{
Simple relationships to predict attributes of fish assemblages in patches of submerged macrophytes
}

\author{
Fernando Mayer Pelicice1, Sidinei Magela Thomaz ${ }^{2}$ and Angelo Antonio Agostinho
}

\begin{abstract}
Submerged macrophytes play an important role in structuring habitats and, therefore, in determining patterns of aquatic biodiversity. Because these plants are widespread in shallow areas of many Neotropical reservoirs, the present work investigated if variables related to habitat structure, measured in patches of submerged macrophytes (Egeria densa and E. najas), can be used to predict fish assemblage attributes (fish density and species richness). Based on patch characteristics at fine spatial extents (macrophyte patches within reservoir arms), we considered plant biomass, volume and proportional volume (i.e. percentage of macrophyte volume in the water column) as potential predictors. Fish and macrophytes were sampled with a $1-\mathrm{m}^{2}$ throw trap in littoral habitats of Rosana Reservoir, Paranapanema River, and simple correlation analyses were performed. Fish richness and abundance were highly correlated with all variables $(\mathrm{R}=0.53$ to 0.90$)$, a relationship consistently observed in all sites. When compared to biomass, plant volume and proportional volume did not yield stronger correlations. We observed stronger correlations when $E$. densa and E. najas patches were analyzed separately (mono-specificity), probably because particular effects of each macrophyte on habitat structuring were removed (e.g. unnoticed morphological differences or unknown effects on habitat quality). The high $\mathrm{R}$ values observed in all pairwise relationships are uncommon in ecological studies, highlighting the predictive potential of variables related to habitat structure. These results suggest that, at small spatial extents, macrophyte biomass may represent an interesting predictor of fish density and richness in reservoirs with extensive colonization of submerged plants.
\end{abstract}

As macrófitas aquáticas submersas desempenham um importante papel na estruturação de hábitats e, por isso, determinam padrões gerais de biodiversidade. Como essas plantas colonizam muitos reservatórios neotropicais, o presente trabalho investigou simples relações capazes de predizer atributos de assembléias de peixes (densidade e riqueza) a partir de variáveis relacionadas à estruturação do habitat, medidas em manchas de macrófitas submersas (Egeria densa e E. najas). Baseando-se em características das manchas em pequenas escalas espaciais (bancos de macrófitas em braços do reservatório), nós consideramos a biomassa de plantas, volume e volume proporcional (percentual de volume de macrófitas na coluna d'água) como preditores em potencial. Peixes e macrófitas foram amostrados com uma armadilha de arremesso $\left(1-\mathrm{m}^{2}\right)$ em hábitats litorâneos do reservatório de Rosana, rio Paranapanema, e correlação simples foram utilizadas para analisar as relações. Todas as variáveis apresentaram correlação positiva com a riqueza e densidade de peixes $(\mathrm{R}=0.53$ to 0.90$)$, uma relação consistentemente observada nos três locais amostrados. Com relação à performance individual de cada variável, o volume e o volume proporcional não aumentaram a magnitude das correlações quando comparados à biomassa de macrófitas. Correlações mais fortes foram observadas quando as manchas de $E$. densa e $E$. najas foram analisadas separadamente (mono-especificidade), provavelmente porque efeitos particulares de cada espécie na estruturação dos hábitats foram removidos (e.g. pequenas diferenças morfológicas ou efeitos na qualidade da água). Os altos valores de correlação (R) observados em todas as relações são incomuns em estudos ecológicos, e enfatizam o potencial preditivo de variáveis relacionadas à estrutura espacial dos hábitats. Esses resultados sugerem que, em pequenas escalas espaciais, a biomassa de macrófitas pode representar um interessante preditor da densidade e riqueza de peixes em reservatórios com ampla colonização de plantas submersas.

Key words: Aquatic plants, Habitat structure, Predictive ecology, Variability, Tropical reservoir.

'Programa de Pós-Graduação em Ecologia de Ambientes Aquáticos Continentais, Universidade Estadual de Maringá, Bloco H90, 5790, Avenida Colombo, 87020-900 Maringá, Paraná, Brazil. fmpelicice@gmail.com

${ }^{2}$ Núcleo de Pesquisas em Limnologia, Ictiologia e Aqüicultura, Universidade Estadual de Maringá, Av. Colombo 5790, 87020-900 Maringá, PR, Brazil.. 


\section{Introduction}

Aquatic macrophytes are an ubiquitous group, particularly in shallow aquatic environments. The variety of life forms (Sculthorpe, 1985) together with their great phenotypic plasticity (Santamaría, 2002) may have influenced the successful colonization of aquatic ecosystems by these plants. In addition, human interference (e.g. eutrophication and river damming) facilitates macrophyte colonization and, depending on limnological conditions, a massive development of free-floating or submerged species can occur (Thomaz \& Bini, 1999; van Nes et al., 2002). Although undesirable effects may be caused by excessive coverage, adversely affecting water and habitat quality and causing conflict among ecosystem users (van Nes et al., 2002), a number of studies have demonstrated that macrophytes play a key role in biodiversity conservation and maintenance of freshwater ecosystem functioning (Carpenter \& Lodge, 1986; Rozas \& Odum, 1988; Chick \& McIvor, 1994; Randall et al., 1996; Engelhardt \& Ritchie, 2001). These aspects highlight the role of aquatic macrophytes as "foundation species" (sensu Bruno et al., 2003).

In Neotropical reservoirs, in particular, patches of macrophytes can be the most important habitat available for fish species, usually juveniles and small body-sized adults. Because impounded rivers undergo significant modifications in landscape and hydrology at different spatial/temporal scales (Petts, 1984; Agostinho et al., 2007a; Mol et al., 2007), it is common that riverine habitats are lost or replaced by huge pelagic areas, which are unsuitable habitats for Neotropical fish fauna (Gomes \& Miranda, 2001; Luz-Agostinho et al., 2006). In this case, habitat quality and quantity may increase dramatically when macrophyte species colonize littoral areas of reservoirs, by creating refuges against predation, new feeding sites, and spawning grounds. For example, recent studies in a Neotropical reservoir found that macrophyte patches with high plant biomass support high fish density and species richness (Pelicice et al., 2005) and constitute a feeding site for juveniles and adults (Casatti et al., 2003; Pelicice \& Agostinho, 2006).

The conflicts between the environmental benefits and economic damage of macrophytes increase the necessity to predict and understand fish assemblages in South American reservoirs, mainly because current management activities overestimate the benefits of reducing macrophyte densities for hydroelectric purposes. Variables such as primary productivity, resource availability, nutrients, lake area and depth (Hanson \& Legget, 1982; Eadie \& Keast, 1984; Downing et al., 1990; Quiros, 1990) have been used to predict fish abundance, biomass and richness at large spatial extents (sensu Wiens, 1989), in temperate/sub-tropical reservoirs and lakes. Attempts to predict fish assemblages in Neotropical reservoirs, however, have produced less-successful results (Gomes \& Miranda, 2001; Gomes et al., 2002; Piana et al., 2005). In these reservoirs, community dynamics are not fully understood and our ability to predict patterns of fish distribution quantitatively is still limited. Consequently, the identification of another set of potential predictor variables is an important step to improve our predictive capacity and to better understand which factors determine fish community structure.

Because of the widespread distribution of macrophytes in aquatic ecosystems, and the predominance of small-sized fish species in South American reservoirs (Agostinho et al., 2007a), we evaluate if basic habitat characteristics can be used to predict fish assemblage attributes in littoral shores of a Neotropical reservoir, over a fine spatial extent (macrophyte patches within reservoir arms). As a first step to develop more accurate predictive tools, we explored relationships of fish richness and abundance associated with patches of submerged macrophytes (Egeria densa Planch. and Egeria najas Planch.) using the following variables: (i) macrophyte biomass, (ii) macrophyte volume and (iii) proportional volume (percentage of macrophyte volume in the water column). In particular, we expect that variables (ii) and (iii) would yield higher correlations than (i), because they quantify the amount of structure in the water column. We then discuss the feasibility of these relationships for modeling and their meaning for predictive fish ecology.

\section{Material and Methods}

\section{Area description}

The Paraná River occupies the second-largest drainage basin in South America. In its upper (Brazilian) stretch, most of the main rivers are dammed and several reservoirs are arranged in cascades (Agostinho et al., 2007a). As a result, limnological conditions (Barbosa et al., 1999) as well as macrophyte assemblages (Thomaz \& Bini, 1999) change in relation to reservoir spatial position, from headwaters to mouth. Substantial development of submerged macrophytes has occurred in reservoirs situated downstream from these cascades, including submerged rooted species of the genus Egeria, a Hydrocharitaceae native from South America.

The present study was conducted in the Rosana Reservoir $\left(22^{\circ} 36^{\prime} \mathrm{S}, 52^{\circ} 52^{\prime} \mathrm{W}\right)$, the last in a cascade of eight reservoirs along the Paranapanema River, one of the main tributaries of the upper Paraná River Basin. The dam was completed in 1986, flooding a shallow area of $276 \mathrm{~km}^{2}$. A map of this reservoir was provided by Pelicice et al. (2005).

About 37 species of aquatic macrophytes are found in this reservoir, belonging to different life forms. The most frequent are Eichhornia azurea, Egeria densa, E. najas, Cabomba furcata, Myriophyllum aquatica, Salvinia spp. and Nymphaea sp., in addition to several Poaceae species (Thomaz et al., 2005). In recent years, E. densa and E. najas have massively colonized shallower littoral areas (depths $<4 \mathrm{~m}$ ), and formed patches with different plant densities. Colonization of submerged macrophytes is favored in Rosana and other reservoirs of this basin, where under-water radiation is barely a limiting factor (Thomaz \& Bini, 1999).

\section{Fish sampling}

Samples were collected in three sites of the reservoir. Two 
sites were sampled daily during the summer 2003, between January 15 and 21. Site 1 was located in the transition zone of the impoundment, upstream from Euclides da Cunha Paulista district, State of São Paulo (22 $34^{\prime} 07^{\prime \prime}$ S, 52 $33^{\prime} 34^{\prime \prime}$ W). Site 2 was located in an impounded stretch of the Corvo River, a small tributary close to the dam in Diamante do Norte district, State of Paraná $\left(22^{\circ} 38^{\prime} 29^{\prime \prime} \mathrm{S}, 52^{\circ} 47^{\prime} 16^{\prime \prime} \mathrm{W}\right)$. The third site was sampled during the spring 2007, between November 28 and 30, and is also located in Euclides da Cunha Paulista district. We selected these sites because shores were massively colonized by Egeria, including thick mats occupying the entire water column.

A $1 \mathrm{~m}^{2}$ throw trap was used to sample fish and macrophytes. The trap was constructed with a $1.5 \mathrm{~m}$ high aluminum frame, and a small mesh $(0.5 \mathrm{~cm})$ covering all four sides. At each site, a boat was slowly and silently positioned above an Egeria patch and used as a platform for trap deployment. Depth was recorded at each sampled patch, all macrophytes were removed from the trap, and E. najas and E. densa were separated, washed and weighed (wet weight measured in g. $\left.\mathrm{m}^{-2}\right)$. After vegetation removal, all fish were collected with an aluminum dip-net $(49 \times 49 \mathrm{~cm}$ frame and $0.5 \mathrm{~cm}$ net mesh size). Several hauls were made inside the trap area, until 10 successive hauls resulted in no additional individual captured. All the fish were preserved in $10 \%$ formalin, taken to the laboratory, and subsequently identified, counted and measured (standard length, $\mathrm{cm}$ ). Fish density and species richness were expressed as individuals. $\mathrm{m}^{-2}$ and species. $\mathrm{m}^{-2}$, respectively, for each patch.

Each throw trap deployment procedure (each Egeria patch) represented an independent sampling unit within sites. A total of 62 samples were analyzed: 19 samples in Site 1, 20 in Site 2 and 23 in Site 3. Sampled patches were visually selected to incorporate various densities of $E$. densa and $E$. najas, restricted to depths $<1.4 \mathrm{~m}$ in near-shore areas (because of sampling equipment limitations). It is worth noting that the range of biomass sampled (see Table 1) was similar to the natural range observed in other reservoirs of the basin (e.g. Thomaz et al., 1998). In addition, we collected samples distributed over a large area in each site ( $>50 \mathrm{ha})$, in order to minimize the influence of spatial autocorrelation.

\section{Habitat structure variables}

To obtain macrophyte biomass in dry mass $\left(\mathrm{g}^{\mathrm{m}} \mathrm{m}^{-2}\right)$ in each patch, sub-samples of plants were retained and dried in the laboratory $\left(60^{\circ} \mathrm{C}\right.$ for 7 days). The coefficient to convert wet biomass (WM; g) into dry biomass (DM; g) was obtained through regression analysis between both variables, using independent plant fragments. Regression between WM and $\mathrm{DM}$ was statistically significant for $E$. densa $\left(\mathrm{n}=22 ; \mathrm{R}^{2}=0.97\right.$; $\mathrm{F}=647.7 ; \mathrm{p}<0.0001 ; \mathrm{DM}=0.096 \times \mathrm{WM})$ and E. najas (n $=39 ; \mathrm{R}^{2}=0.94 ; \mathrm{F}=627.9 ; \mathrm{p}<0.0001 ; \mathrm{DM}=0.087 \times \mathrm{WM}$ ), and intercepts were not different from zero. These regression models were used to estimate total dry biomass in each sample.

Volumes ( $\mathrm{ml}$ ) of 29 plants collected in the field (E. densa, $\mathrm{n}=15 ; E$. najas, $\mathrm{n}=14$ ) were measured as displacement of water using a $500 \mathrm{ml}$ graduated cylinder. As before, the coefficient to convert plant dry biomass (DM; g) into plant volume (VOL; $\mathrm{ml}$ ) was obtained through regression analysis between both variables $\left(E\right.$. densa: $\mathrm{R}^{2}=0.82 ; \mathrm{F}=60.9 ; \mathrm{p}<$ $0.0001 ; \mathrm{VOL}=10.97 \times \mathrm{DM})\left(\right.$ E. najas: $\mathrm{R}^{2}=0.91 ; \mathrm{F}=126.9$; $\mathrm{p}<0.0001 ; \mathrm{VOL}=15.59 \times \mathrm{DM})$. The intercepts were not statistically different from zero, and these models were used to estimate total plant volume in each sample.

Finally, to calculate the proportional plant volume (percentage of macrophyte volume in the water column), total plant volume $(\mathrm{ml})$ in the patch was divided by total water volume $(\mathrm{ml})$. The calculation of water volume considered depth measure $(\mathrm{cm})$ in the area of the trap $\left(1 \mathrm{~m}^{2}\right)$.

\section{Fish-habitat relationships}

To investigate the correlation between habitat spatial structure and fish assemblage attributes, we explored three relationships, considering the following variables: (i) macrophyte dry biomass (BIOM), (ii) macrophyte volume (VOL) and (iii) proportional macrophyte volume (\%VOL). Variables BIOM and VOL represent the amount of under-water structure, but they may fail to surrogate microhabitat complexity in some circumstances, especially when the plants are morphologically simple or different life forms are present. Egeria species, however, show intermediate levels of spatial complexity compared to other macrophytes (Dibble \& Thomaz, 2006), E. densa and E. najas have similar architecture (Cook \& UrmiKonig, 1984), and no other macrophyte species was recorded in the sampled patches. These assumptions make our patches comparable and justify the use of these variables as surrogates of submerged spatial structure.

Simple linear correlations were used to evaluate the relationship between fish assemblage attributes (ATB: fish density and species richness) and the variables mentioned previously. Pearson's product-moment correlation ( $\mathrm{R}$ ) was used to assess changes in the strength of relationships. To investigate the recurrence of relationships, we performed these analyses for each site separately and for all three sites pooled.

Our initial intention was to analyze relationships between ATB and habitat structure considering Egeria patches as a whole, since both species are morphologically similar. In situ observations, however, suggested differences in the physical density (i.e., volume/weight) between $E$. densa and E. najas. A covariance analysis (ANCOVA) confirmed that the slopes of volume-biomass relationships differ between these species (interaction species*biomass: $\mathrm{F}_{1 ; 25}=5.22 ; \mathrm{p}=0.031$ ). In this case, E. najas showed a more rapid increase in volume per biomass; E. najas has about $30 \%$ more plant material (volume) per mass when compared to $E$. densa. Therefore, considering that (i) unequal physical density between Egeria species may result in different levels of spatial structure per plant weight, (ii) that unnoticed architectural differences may have some effect on habitat quality, and (iii) that either E. densa or E. najas tended to dominate each patch, we extended the analyses to explore separately each patch type (predominance of $E$. densa or E. najas). Predominance was considered when one species 
represented more than $50 \%$ of the total biomass. So, to explore effects of mono-specificity we repeated correlation analyses between ATB and habitat variables separately for each patch type; in this case, predominance of $E$. densa and E. najas.

The software STATISTICA version 7.0 (Statsoft, 2005) was used for all analyses, and statistical significance implied an $\alpha<0.05$. Assumptions of parametric tests were checked through residual analysis.

\section{Results}

\section{Habitat characteristics}

In all 62 samples, depth ranged from 0.6 to $1.3 \mathrm{~m}$ and macrophyte beds formed patches with biomass ranging from 1.2 to 303.8 DM g.m $\mathrm{m}^{-2}$ (Table 1), with mean of $136.5 \mathrm{~g} . \mathrm{m}^{-2}$; one sample had an uncommon high value (529.1 g.m $\left.\mathrm{m}^{-2}\right)$. We observed variation among sites, as for example, Site 2 had patches colonizing slightly deeper places, with lower values of mean plant biomass (Table 1). Sites 1 and 3, both located in Euclides da Cunha district, showed similar characteristics.

Table 1. Characteristics of Egeria patches $\left(1 \mathrm{~m}^{2}\right)$ sampled in three sites in the Rosana Reservoir (Site 1: $\mathrm{n}=19$; Site 2: $\mathrm{n}$ $=20$; Site $3: \mathrm{n}=23$ ).

\begin{tabular}{|c|c|c|c|c|c|c|}
\hline \multirow[t]{2}{*}{ Variables } & \multicolumn{2}{|c|}{ Site 1} & \multicolumn{2}{|c|}{ Site 2} & \multicolumn{2}{|c|}{ Site 3} \\
\hline & $\begin{array}{l}\text { mean } \\
(\mathrm{SD})\end{array}$ & range & $\begin{array}{l}\text { mean } \\
(\mathrm{SD})\end{array}$ & range & $\begin{array}{l}\text { mean } \\
(\mathrm{SD})\end{array}$ & range \\
\hline $\begin{array}{l}\text { Depth } \\
\text { (cm) }\end{array}$ & $\begin{array}{c}89.2 \\
(13.2)\end{array}$ & $60-120$ & $\begin{array}{l}107.4 \\
(13.1)\end{array}$ & $80-130$ & $\begin{array}{c}83.7 \\
(13.2)\end{array}$ & $60-120$ \\
\hline $\begin{array}{l}\text { Biomass } \\
\left(\mathrm{g} \cdot \mathrm{m}^{-2}\right)\end{array}$ & $\begin{array}{c}147.2 \\
(133.5)\end{array}$ & $1.5-529.1$ & $\begin{array}{c}80.3 \\
(69.9)\end{array}$ & $1.2-293$ & $\begin{array}{l}176.6 \\
(71.6)\end{array}$ & $50.9-303.8$ \\
\hline $\begin{array}{l}\text { Volume } \\
\left(\mathrm{ml} . \mathrm{m}^{-2}\right)\end{array}$ & $\begin{array}{c}1696.8 \\
(1543.6)\end{array}$ & $16.8-6050.2$ & $\begin{array}{l}1181.2 \\
(927.7)\end{array}$ & $18.7-3612.9$ & $\begin{array}{l}1937.6 \\
(785.1)\end{array}$ & $558.2-3333.1$ \\
\hline $\begin{array}{l}\text { Volume } \\
(\%)\end{array}$ & $\begin{array}{c}0.18 \\
(0.15)\end{array}$ & $0.01-0.58$ & $\begin{array}{c}0.11 \\
(0.08)\end{array}$ & $0.01-0.31$ & $\begin{array}{c}0.23 \\
(0.09)\end{array}$ & $0.06-0.41$ \\
\hline $\begin{array}{l}\text { Fish density } \\
\left(\text { ind. } m^{-2} \text { ) }\right.\end{array}$ & $\begin{array}{c}10.3 \\
(12.4)\end{array}$ & $0-38$ & $\begin{array}{c}7.6 \\
(7.3)\end{array}$ & $0-22$ & $\begin{array}{c}6.5 \\
(7.0)\end{array}$ & $0-24$ \\
\hline $\begin{array}{l}\text { Fish richness } \\
\left(\mathrm{spp} \cdot \mathrm{m}^{-2}\right)\end{array}$ & $\begin{array}{c}2.9 \\
(2.9)\end{array}$ & $0-8$ & $\begin{array}{c}2.9 \\
(2.4)\end{array}$ & $0-8$ & $\begin{array}{c}2.3 \\
(1.6)\end{array}$ & $0-6$ \\
\hline $\begin{array}{l}\text { Fish body } \\
\text { length (Ls, } \\
\mathrm{cm})\end{array}$ & $\begin{array}{c}3.6 \\
(4.0)\end{array}$ & $1.3-35$ & $\begin{array}{c}2.9 \\
(0.9)\end{array}$ & $1.4-6.7$ & $\begin{array}{c}3.1 \\
(1.4)\end{array}$ & $1.4-10.5$ \\
\hline
\end{tabular}

Forty three patches were dominated by $E$. densa (more than $50 \%$ DM biomass) and the remaining 19 were dominated by E. najas (Table 2). One patch showed similar proportions of E. densa (52\%) and E. najas (48\%) biomass, but we decided to categorize it as E. najas-dominated because this species prevailed in terms of volume and underwater structure. In general, patches with predominance of $E$. densa had some contribution of $E$. najas ( 0 to $39 \%$; mean $=11 \%$ ), whereas patches with predominance of $E$. najas tended to be monospecific ( 0 to $6 \%$ of $E$. densa contribution; mean $=0.03 \%$ ). Higher mean values of biomass (BIOM), volume (VOL) and proportional volume (\%VOL) were observed in E. densadominated patches. Egeria najas patches occurred mainly in Site 2, which showed greater mean depth.
Table 2. Habitat characteristics of $1 \mathrm{~m}^{2}$ patches with predominance of Egeria densa $(\mathrm{n}=43)$ and Egeria najas $(\mathrm{n}=19)$.

\begin{tabular}{lcccc}
\hline Habitat & \multicolumn{2}{c}{ E. densa } & \multicolumn{2}{c}{ E. najas } \\
variables & mean(SD) & range & mean(SD) & range \\
\hline Depth $(\mathrm{cm})$ & $87.6(16.6)$ & $60-130$ & $105.4(12.2)$ & $80-127$ \\
Biomass $\left(\mathrm{g} . \mathrm{m}^{-2}\right)$ & $166.6(104.4)$ & $1.5-529.1$ & $68.4(49.1)$ & $1.2-132.8$ \\
Volume $\left(\mathrm{ml} . \mathrm{m}^{-2}\right)$ & $1872.9(1196.7)$ & $16.8-6050.2$ & $1046.8(743.3)$ & $18.7-2024.8$ \\
Volume $(\%)$ & $0.21(0.12)$ & $0.003-0.58$ & $0.10(0.07)$ & $0.002-0.20$ \\
\hline
\end{tabular}

\section{Fish-habitat relationships}

A total of 496 individuals belonging to 22 fish species were caught in the 62 samples. The fish assemblage associated with Egeria patches was composed by small-sized species (Tab. 1), mainly Characiformes ( $88 \%$ of total abundance). The most abundant species were Hemigrammus marginatus, Hyphessobrycon eques, Roeboides descalvadensis, Serrapinnus notomelas and Serrasalmus marginatus. Other fish taxa registered were Gymnotiformes, Cichlidae and Siluriformes. In general, mean fish richness was similar among sites, while fish density was slightly higher in Site 1 (Tab. 1). More details about the composition of fish assemblages associated to submerged macrophytes in the Rosana Reservoir are given by Pelicice et al. (2005).

Fish density and richness were positively correlated with all habitat variables in the three sites. All correlations were statistically significant $(\mathrm{p}<0.05)$ and relationships showed linear trends. Fish density was moderately or strongly correlated with BIOM, with some among-site variation in the strength of relationships $(0.53<\mathrm{R}<0.73)$ (Fig. 1a). Differing from expected, correlation strength did not increase with VOL and \%VOL, either for sites analyzed independently or for all sites pooled (Fig. 1a). Fish richness was in general strongly correlated with BIOM, despite some among-site variation $(0.60<\mathrm{R}<0.84)$ (Fig. 1b). Again, correlation strength did not increase with VOL and VOL\% (Fig. 1b).

When analyzing the relationship between ATB and habitat variables in patches dominated by E. densa or E. najas separately, we observed stronger correlations than the relationship observed with all data pooled (Fig. 2). The highest correlations were observed in $E$. najas patches, with $\mathrm{R}$ values ranging from 0.75 to 0.90 , for both fish density (Fig. 2a) or species richness (Fig. 2b). High correlations were also registered in E. densa patches, which ranged from 0.68 to 0.78 (Fig. 2). Again, the strength of the correlations was similar among all habitat variables.

Because correlations were higher in mono-specific patches, we performed an ANCOVA to test if the relationship between $\mathrm{ATB}$ and BIOM differ in E. densa and E. najas patches, considering plant dry biomass as a co-variable. The interaction term (species $x$ biomass) was statistically significant for fish density $\left(\mathrm{F}_{1 ; 58}=10.05 ; \mathrm{p}=0.002\right)$ and richness $\left(\mathrm{F}_{1 ; 58}=18.05 ; \mathrm{p}\right.$ $=0.0001)$. In this case, $E$. najas patches showed higher slope values $\left(\beta_{\text {density }}=0.16 ; \beta_{\text {richness }}=0.04\right)$ than did E. densa $\left(\beta_{\text {density }}\right.$ $=0.06 ; \beta_{\text {richness }}=0.02$ ). Even though Egeria species are very similar in morphology, the present results indicate that, when 

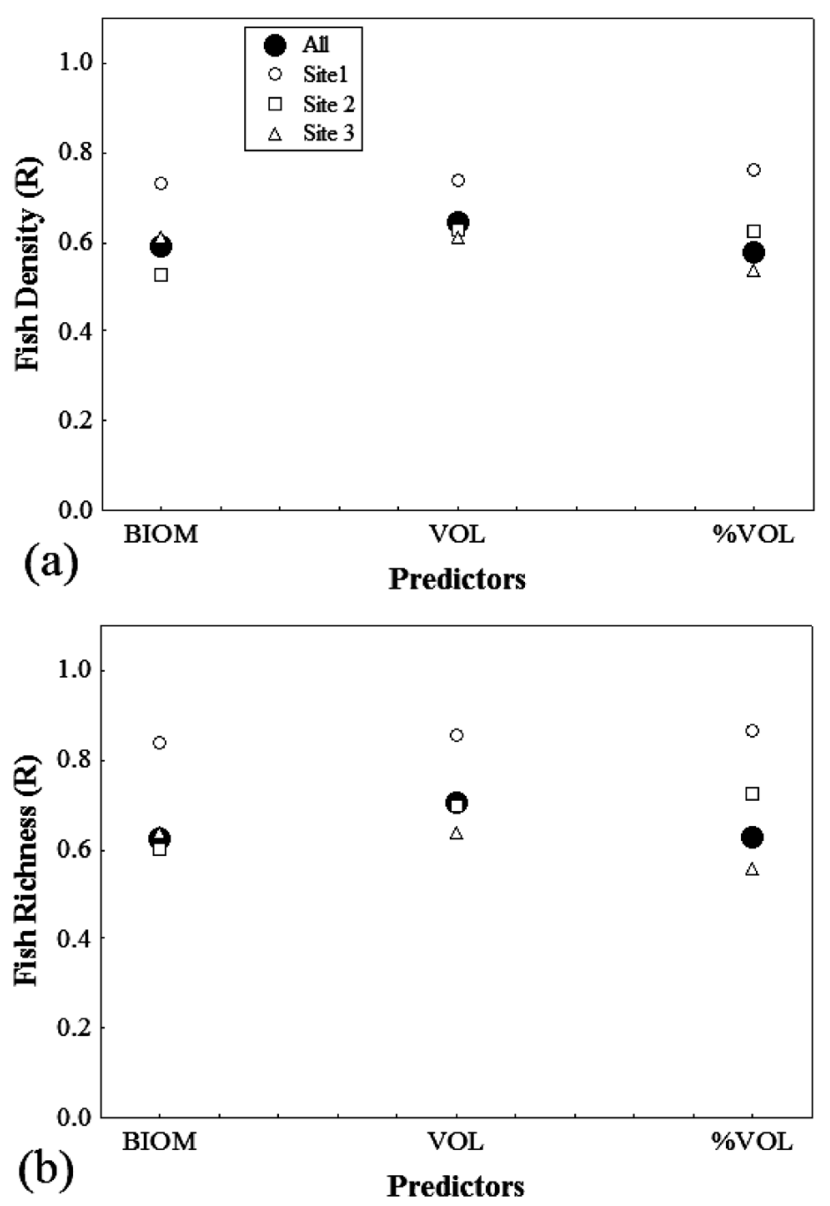

Fig. 1. Correlation coefficients (Pearson's R) obtained from relationships between fish assemblage attributes (a: density; $b$ : species richness) and habitat variables (macrophyte biomass, BIOM; volume, VOL; proportional volume, \%VOL) in Egeria patches. We show results from each site (Site 1,2 and 3) and all data pooled (All). All correlations were statistically significant $(\mathrm{p}<0.05)$.

plant biomass is controlled, higher values of fish density and richness are expected in E. najas-dominated patches (Fig. 3).

\section{Discussion}

Attempts to predict fish assemblages and fishery yields in inland waters have considered variables related to site productivity, area and depth (Hanson \& Legget, 1982; Eadie \& Keast, 1984; Downing et al., 1990; Quiros, 1990). In Neotropical freshwaters, the prediction has challenged scientists for decades, and no obvious solution has been proposed (Gomes $\&$ Miranda, 2001). The present study showed that variables related to habitat structure in shallow shores (e.g. plant biomass and volume) were strongly correlated to attributes of fish assemblages in Rosana Reservoir, at the spatial extents (macrophyte patches within arms of the reservoir) and grains $\left(1 \mathrm{~m}^{2}\right.$ quadrats) used in our work. Therefore, we propose that surrogates of habitat spatial structure, such as macrophytes, represent an effective tool to predict fish assemblages in
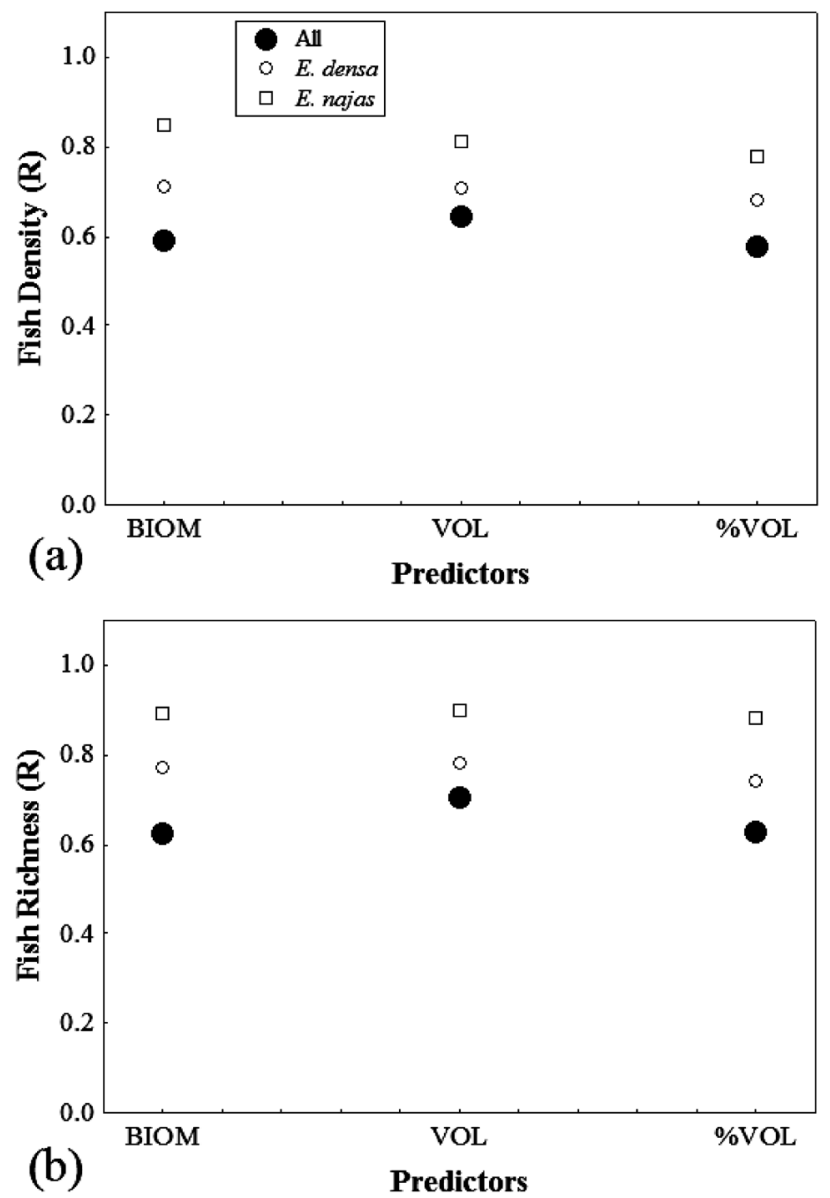

Fig. 2. Correlation coefficients (Pearson's R) obtained from relationships between fish assemblage attributes (a: density; b: species richness) and habitat variables (macrophyte biomass, BIOM; volume, VOL; proportional volume, \%VOL). We show correlation results from all patches (All), patches dominated by $E$. densa and patches dominated by E. najas. All correlations were statistically significant $(\mathrm{p}<0.05)$.

Rosana or other reservoirs with extensive colonization of submerged plants (e.g. Paraná, Tietê, Paranapanema basins), at least over small spatial extents.

In our study, macrophyte biomass, volume and proportional volume were strongly correlated with fish density and species richness, a pattern also observed in other studies (Valley \& Bremigan, 2002; Crawley et al., 2006). The recurrence of these relationships in three independent sites of the reservoir supports the pattern, suggesting that macrophytes play an important role influencing fish distribution in littoral areas. One important aspect behind these relationships is the nature of fish assemblages in reservoirs, which are composed by many small-sized species (Agostinho et al., 2007a). Because minute species are vulnerable to predation and can efficiently use microhabitats, they have a strong dependence on smallscale habitat structure, responding promptly to changes in habitat quantity and quality (Vono et al., 2001; Petry et al., 2003; Pelicice et al., 2005; Agostinho et al., 2007b). Habitatbased metrics, such as macrophytes, logs, trunks, and stones, 


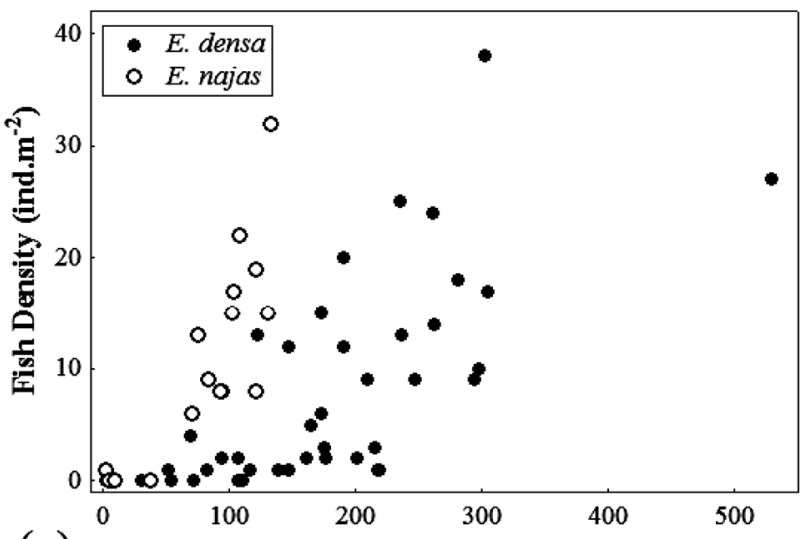

(a) Macrophyte Biomass (g.m $\left.{ }^{-2}\right)$

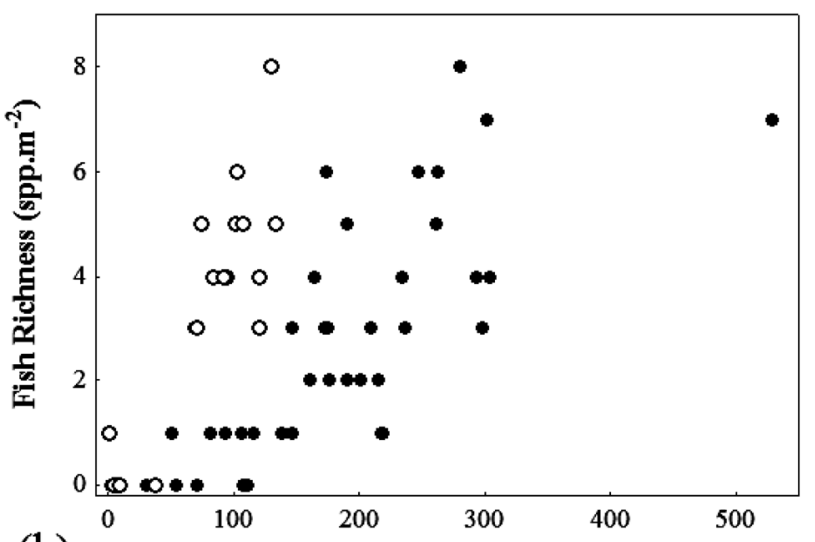

(b) Macrophyte Biomass (g.m ${ }^{-2}$ )

Fig. 3. Relationships between macrophyte biomass and fish density (a) and species richness (b), in patches dominated by E. densa and E. najas.

are surrogates for several environmental properties that are important for fish assemblages, including site productivity, food availability, spawning sites and protection (Rozas \& Odum, 1986; Chick \& McIvor, 1994; Casatti et al., 2003; Garcia et al., 2005; Pelicice \& Agostinho, 2006; Sass et al., 2006). Therefore, any increase in plant biomass is probably associated with the availability of more microhabitat for fish (i.e., increase in stem and leaf density).

The three measured habitat variables showed similar strength in correlations with assemblage attributes. We expected that VOL, and especially \%VOL, would yield higher correlations than BIOM. While VOL accounts for total underwater structure and can remove differences in physical density and plant morphology (at least for plants with similar architecture), \%VOL quantifies the proportional amount of underwater structure. However, the variable VOL was unable to reflect differential physical density between Egeria species; an effect observed only when Egeria patches were analyzed separately. Similarly, \%VOL did not yield stronger correlations. This pattern is probably associated to the variation in depth among patches $(60-130 \mathrm{~cm})$, and the strong association between fish assemblages and macrophyte biomass. If fish density and richness are strongly related to macrophyte biomass alone, deep and shallow patches with similar biomass supposedly harbor similar amounts of fish; however, while macrophyte biomass is similar, \%VOL is lower in deep patches, which interferes on correlations with ATB. Therefore, because biomass is strongly correlated with fish density and richness, and it can be easily quantified in the field, predictive models should focus on assessing biomass of macrophytes (or other important submerged structure) to predict fish spatial dynamics in littoral areas of reservoirs.

It is important to point out, however, that we studied beds formed by only two macrophyte species ( $E$. densa and $E$. najas), both with similar architecture and intermediate levels of morphological complexity (Cook \& Urmi-Konig, 1984; Dibble \& Thomaz, 2006). If patches have different macrophyte life forms (e.g. submerged dissected leaves, ribbon-like stems, floating leaves), we presume that neither biomass nor volume measures will represent microhabitat structure. Even in our case, effects related to macrophyte species were clear. Egeria densa and E. najas have similar morphology, but they differed in physical density: Egeria najas has more plant matter per unit biomass (i.e., higher plant density), resulting in increased habitat structure and fish density $/ \mathrm{m}^{2}$. Biomass cannot account for this feature when both species coexist, which, consequently, was reflected on correlation strength. For example, correlations improved between 20 and $43 \%$ when patches of $E$. densa and E. najas were uncoupled (Fig. 2). Besides removing effects related to physical density, other idiosyncrasies (such as unnoticed morphological differences or unknown effects on habitat quality) may be accounted for when mono-specific patches are analyzed. Under such circumstances, macrophyte biomass may constitute an adequate predictor. On the other hand, if patches have many coexisting macrophyte species, the use of alternative metrics such as the index of morphological complexity (Dibble \& Thomaz, 2006) or fractal geometry (Thomaz et al., 2008), combined with quantitative measures (as biomass), seems more appropriate. In this case, we presume that predictions at small spatial extents will become more complex and difficult, because surface area effects (e.g. macrophyte density) as well as microhabitat complexity (e.g. morphological traits) must be taken into consideration.

The most interesting results were the uncommonly high correlation values that characterized all relationships. Converting product-moment correlations $(\mathrm{R})$ to coefficient of determination $\left(\mathrm{R}^{2}\right)$, we observed that much of the variability in fish assemblages was explained by a single variable $\left(\mathrm{R}^{2}\right.$ range $=28-81 \%$; mean $=50 \%$ ), since we analyzed only simple pairwise relationships. Community ecology is inherently characterized by a high degree of natural variability due to the idiosyncrasies of individuals, complex interactions, multiple and indirect causation and emergence. These aspects add noise to any ecological pattern (Strong, Jr., 1983; Moller \& Jennions, 2002) and make quantitative prediction a difficult - but not impossible - goal (Rigler, 1982; Peters, 1986; Pace, 2001). High levels of determinism and predictive power are observed more often in controlled laboratory experiments, in allometric relationships or in models with multiple predictors. 
It is important to emphasize that the present study was only a field-sampling project that analyzed simple pairwise relationships, which reinforces the non-random nature of fish-plant associations. Macrophyte biomass, for instance, was able to explain about $60 \%$ and $80 \%$ of variability in fish species richness in E. densa and E. najas patches, respectively; similarly, biomass explained up to $72 \%$ of variability in fish density. Even if correlations were overestimated to some extent (see Hakanson \& Peters, 1995), their predictive potential seems unquestionable. In this case, a possible source of variability is the shoaling behavior of many small-sized species, which constantly move among patches and increases the chance of capturing few or many individuals in a single sample.

Concluding, based on evidences observed in Rosana Reservoir, we suggest that habitat-based variables have a remarkable predictive potential at fine spatial extents. Because aquatic plants are widely distributed in shallow areas of many South American reservoirs, macrophyte attributes (biomass, volume) constitute an interesting option to predict fish assemblages. Therefore, the recurrence of such potential among reservoirs deserves investigation; the inclusion of different data sets, obtained at larger extents and including other reservoirs or seasons, will help to confirm or modify these patterns. In addition, a further step to develop our simple relationships is to determine fish-macrophyte associations in multi-species beds and in different spatial scales, particularly to investigate the influence of macrophyte richness and distribution on the fish fauna. Equally, understanding other environmental factors involved and, particularly, how small-sized species are linked to commercially important species (such as large piscivores), would certainly improve predictions about fish production and diversity in Neotropical reservoirs.

\section{Acknowledgements}

We are deeply indebted to Eric D. Dibble (Mississippi State University), who gave important insights and reoriented appreciably the idea behind this work. David J. Hoeinghaus (Kansas State University) and Luis M. Bini (Universidade Federal de Goiás, Brazil) also provided helpful comments on the manuscript. CAPES/CNPq provided a scholarship to the first author. S. M. Thomaz and A. A. Agostinho are grateful to the Conselho Nacional de Desenvolvimento Científico e Tecnológico - Brazil (CNPq) for continuous funding through a Productivity Research Grant.

\section{Literature Cited}

Agostinho, A. A., L. C. Gomes \& F. M. Pelicice. 2007a. Ecologia e manejo de recursos pesqueiros em reservatórios do Brasil. Maringá, Eduem, 501p.

Agostinho, A. A., S. M. Thomaz, L. C. Gomes \& S. L. S. M. A. Baltar. 2007b. Influence of the macrophyte Eichhornia azurea on fish assemblage of the Upper Paraná River floodplain (Brazil). Aquatic Ecology, 41: 611-619.
Barbosa, F. A. R., J. Padiská, E. L. G. Espíndola, G. Borics \& O. Rocha. 1999. The cascading reservoir concept (CRCC) and its application to the river Tietê-Basin, São Paulo State, Brazil. Pp. 425-437. In: Tundisi J. G. \& M. Straskraba (Eds.). Theoretical reservoir ecology and its applications. São Carlos, Brazilian Academy of Sciences and Backhuys Publishers, 585p.

Bruno, J. F., J. J. Stachowicz \& M. D. Bertness. 2003. Inclusion of facilitation into ecological theory. Trends in Ecology and Evolution, 30: 1-7.

Carpenter, S. R. \& D. M. Lodge. 1986. Effects of submersed macrophytes on ecosystem processes. Aquatic Botany, 26: 341-370.

Casatti, L., H. F. Mendes \& K. M. Ferreira. 2003. Aquatic macrophytes as feeding site for small fishes in the Rosana reservoir, Paranapanema River, Southeastern Brazil. Brazilian Journal of Biology, 63: 213-222.

Chick, J. H. \& C. C. McIvor. 1994. Patterns in the abundance and composition of fishes among beds of different macrophytes: viewing a littoral zone as a landscape. Canadian Journal of Fisheries and Aquatic Sciences, 51: 2873-2882.

Cook, C. D. K. \& K. Urmi-Konig. 1984. A revision of the genus Egeria (Hydrocharitaceae). Aquatic Botany, 19: 73-96.

Crawley, K. R., G. A. Hyndes \& S. G. Ayvazian. 2006. Influence of different volumes and types of detached macrophytes on fish community structure in surf zones of sandy beaches. Marine Ecology Progress Series, 307: 233-246.

Dibble, E. D. \& S. M. Thomaz. 2006. A simple method to estimate spatial complexity in aquatic plants. Brazilian Archives in Biology and Technology, 49: 421-428.

Downing, J. A., C. Plante \& S. Lalonde. 1990. Fish production correlated with primary productivity, not the morphoedaphic index. Canadian Journal of Fisheries and Aquatic Sciences, 47: 1929-1936.

Eadie, J. M. \& A. Keast. 1984. Resource heterogeneity and fish species diversity in lakes. Canadian Journal of Zoology, 62: 1689-1695.

Engelhardt, K. A. M. \& M. E. Richtie. 2001. Effects of macrophyte species richness on wetland ecosystem functioning and services. Nature, 411: 687-689.

Garcia, A. M., R. M. Geraldi \& J. P. Vieira. 2005. Diet composition and feeding strategy of the southern pipefish Syngnathus folletti in a Widgeon grass bed of the Patos Lagoon Estuary, RS, Brazil. Neotropical Ichthyology, 3: 427-432.

Gomes, L. C. \& L. E. Miranda. 2001. Riverine characteristics dictate composition of fish assemblages and limit fisheries in reservoirs of the upper Paraná River Basin. Regulated Rivers: Research and Management, 17: 67-76.

Gomes, L. C., L. E. Miranda \& A. A. Agostinho. 2002. Fishery yield relative to chlorophyll a in reservoirs of the Upper Paraná River, Brazil. Fisheries Research, 55: 335-340.

Hakanson, L. \& R. H. Peters. 1995. Predictive limnology: methods for predictive modeling. Amsterdam, The Netherlands, SPB Academic Publishing, 464p.

Hanson, J. M. \& W. C. Legget. 1982. Empirical prediction of fish biomass and yield. Canadian Journal of Fisheries and Aquatic Sciences, 39: 257-263.

Luz-Agostinho, K. D. G., L. M. Bini, R. Fugi, A. A. Agostinho \& H. F. Júlio Junior. 2006. Food spectrum and trophic structure of the ichthyofauna of Corumbá reservoir, Paraná river Basin, Brazil. Neotropical Ichthyology, 4: 61-68.

Mol, J. H., B. de Mérona, P. E. Ouboter \& S. Sahdew. 2007. The fish fauna of Brokopondo Reservoir, Suriname, during 40 years of impoundment. Neotropical Ichthyology, 5: 351-368. 
Moller, A. P. \& M. D. Jennions. 2002. How much variance can be explained by ecologists and evolutionary biologists? Oecologia, 132: 492-500.

Pace, M. L. 2001. Prediction and the aquatic sciences. Canadian Journal of Fisheries and Aquatic Sciences, 58: 63-72.

Pelicice, F. M., A. A. Agostinho \& S. M. Thomaz. 2005. Fish assemblages associated with Egeria in a tropical reservoir: investigating the effects of plant biomass and diel period. Acta Oecologica, 27: 9-16.

Pelicice, F. M. \& A. A. Agostinho. 2006. Feeding ecology of fishes associated with Egeria spp. patches in a tropical reservoir, Brazil. Ecology of Freshwater Fish, 15: 10-19.

Peters, R. H. 1986. The role of prediction in limnology. Limnology and Oceanography, 31: 1143-1159.

Petry, P., P. B. Bayley \& D. F. Markle. 2003. Relationships between fish assemblages, macrophytes and environmental gradients in the Amazon River floodplain. Journal of Fish Biology, 63: 547-579.

Petts, G. E. 1984. Impounded rivers: perspectives for ecological management. Chichester, J. Wiley \& Sons, 326p.

Piana, P. A., K. D. Gaspar da Luz, F. M. Pelicice, R. S. Costa, L. C. Gomes \& A. A. Agostinho. 2005. Predição e mecanismos reguladores da biomassa de peixes em reservatórios. Pp. 303310. In: Rodrigues L., S. M. Thomaz, A. A. Agostinho \& L. C. Gomes (Eds.). Biocenoses em reservatórios: padrões espaciais e temporais. São Carlos, RiMa, 321p.

Quiros, R. 1990. Predictors of relative fish biomass in lakes and reservoirs of Argentina. Canadian Journal of Fisheries and Aquatic Sciences, 47: 928-939.

Randall, R. G., C. K. Minns, V. M. Cairns \& J. E. Moore. 1996. The relationship between an index of fish production and submerged macrophytes and other habitat features at three littoral areas in the Great Lakes. Canadian Journal of Fisheries and Aquatic Sciences, 53: 35-44.

Rigler, F. H. 1982. Recognition of the possible: an advantage of empiricism in ecology. Canadian Journal of Fisheries and Aquatic Sciences, 39: 1323-1331.

Rozas, L. P. \& W. E. Odum. 1988. Occupation of submerged aquatic vegetation by fishes: testing the roles of food and refuge. Oecologia, 77: 101-106.

Santamaría, L. 2002. Why are most aquatic plants widely distributed? Dispersal, clonal growth and small-scale heterogeneity in a stressful environment. Acta Oecologica, 23: 137-154.
Sass, G. G., C. M. Gille, J. T. Hinke \& J. F. Kitchell. 2006. Wholelake influences of littoral structural complexity and prey body morphology on fish predator-prey interactions. Ecology of Freshwater Fish, 15: 301-308.

Sculthorpe, C. D. 1985. The biology of aquatic vascular plants. Konigstein, Koeltz Scientific Books, 610p.

Statsoft. 2005. Statistica (data analysis software system). Version 7.1, Tulsa, StatSoft Inc.

Strong Jr., D. R. 1983. Natural variability and the manifold mechanisms of ecological communities. American Naturalist, 122: 636-660.

Thomaz, S. M. \& L. M. Bini. 1999. A expansão das macrófitas aquáticas e implicações para o manejo de reservatórios: um estudo na represa de Itaipu. Pp. 599-626. In: Henry, R. (Ed.). Ecologia de reservatórios: estrutura, função e aspectos sociais. Botucatu, FAPESP/FUNDIBIO, 799p.

Thomaz, S. M., L. M. Bini, \& D. C. Souza. 1998. Biomass and maximum colonization depth of Egeria najas Planchon (Hydrocharitaceae) at Itaipu Reservoir, Brazil. Pp. 223-226. In: Monteiro, A., T. Vasconcelos \& L. Catarino. (Eds). Proceedings of the 10th EWRS International Symposium on Aquatic Weeds. Lisbon, EWRS.

Thomaz, S. M., E. D. Dibble, L. R. Evangelista, J. Higuti \& L. M. Bini. 2008. Influence of aquatic macrophyte habitat complexity on invertebrate abundance and richness in tropical lagoons. Freshwater Biology, 53: 358-367.

Thomaz, S. M., T. A. Pagioro, L. M. Bini \& M. C. Roberto. 2005. Ocorrência e distribuição espacial de macrófitas aquáticas em reservatórios. Pp. 281-292. In: Rodrigues L., S. M. Thomaz, A. A. Agostinho \& L. C. Gomes (Eds.). Biocenoses em reservatórios: padrões espaciais e temporais. São Carlos, RiMa, 321p.

Valley, R. D. \& M. T. Bremigan. 2002. Effects of macrophyte bed architecture on largemouth bass foraging: implications of exotic macrophyte invasions. Transactions of the American Fisheries Society, 131: 234-244.

van Nes, E. H., M. Scheffer, M. S. van den Berg \& H. Coops. 2002. Aquatic macrophytes: restore, eradicate or is there a compromise? Aquatic Botany, 72: 387-403.

Vono, V. \& F. A. R. Barbosa. 2001. Habitats and littoral zone fish community structure of two natural lakes in southeast Brazil. Environmental Biology of Fishes, 61: 371-379.

Wiens, J. A. 1989. Spatial scaling in ecology. Functional Ecology, 3: 385-397. 